\title{
Nursing diagnosis in older adults at risk for pressure injury*
}

\author{
Diagnóstico de enfermagem em pessoa idosa com risco para lesão por pressão \\ Diagnóstico de enfermería en personas mayores con riesgo de lesión por presión
}

How to cite this article:

Garcia EQM, Silva BT, Abreu DPG, Roque TS, Sousa, JIS, Ilha S. Nursing diagnosis in older adults at risk for pressure injury. Rev Esc Enferm USP. 2021;55:e20200549. doi: https://doi.org/10.1590/1980-220X-REEUSP-2020-0549

\section{Eduarda de Quadros Morrudo Garcia ${ }^{1}$

iD Bárbara Tarouco da Silva ${ }^{1}$
D Daiane Porto Gautério Abreu ${ }^{1}$
iD Thicianne da Silva Roque ${ }^{1}$
D José Ismar dos Santos Sousa ${ }^{1}$
iD Silomar Ilha ${ }^{2}$

* Extracted from the dissertation "Perfil de pessoas idosas hospitalizadas: fatores de risco, prevalência e intervenções para prevenção de lesões por pressão",

Programa de Pós-Graduação em Enfermagem, Universidade Federal do Rio Grande, 2020.

${ }^{1}$ Universidade Federal do Rio Grande. Rio Grande, Rio Grande, RS, Brazil.

${ }^{2}$ Universidade Franciscana, Santa Maria, RS, Brazil.

\begin{abstract}
Objective: To develop nursing diagnoses and care plans for older adults with pressure injuries based on risk factors, aiming at preventing their occurrence in hospitalized older adults. Method: Exploratory, descriptive, cross-sectional, quantitative study conducted with 87 medical records at the Medical Clinic Unit of a University Hospital. Results: Among older adults at some risk for the development of pressure injury, there was a prevalence of the female sex, age over 80 years and moderate risk classification on the Braden Scale. Nursing interventions that encourage patient mobility, pressure control, skin supervision, nutrition, incontinence and hygiene stood out. Conclusion: Nursing has an important role in maintaining the integrity of patients' skin. It is worth highlighting the use of injury predictive scales as a complement to clinical practice in order to assist in the nursing diagnosis with a view to interventions aimed at risk factors.
\end{abstract}

DESCRIPTORS

Aged; Hospitalization; Pressure Ulcer; Nursing Diagnosis; Nursing Care. 


\section{INTRODUCTION}

Pressure injuries (PI) are chronic wounds that occur due to compression of the skin with a surface for a prolonged time, leading to cell death. This usually occurs in an area of bone prominence and may be related to the use of medical devices. They can be classified in stages from 1 to 4 , which represent the extent of skin damage in ascending order. Such damage is determined by the intensity and duration of the pressure and is influenced by intrinsic and extrinsic factors. Intrinsic factors are related to the organism itself, such as reduction and/or loss of sensation, muscle strength and immobility. Extrinsic factors refer to influences of the external environment, such as friction, shear and humidity ${ }^{(1)}$.

By taking into account the intrinsic and extrinsic factors influencing PI, the population of older adults is at significant risk for its development. In addition to physiological aging, called senescence, that may be linked to the decline in homeostatic reserves and the response to aggression; there is senility, a term related to diseases and external causes that subsequently result in multiple comorbidities and represent the main cause of disabilities in older adults. Both senility and senescence can trigger functional dependence, which further affects homeostatic reserves and generates a vicious cycle associated with the progression of disabilities, hospitalization and death ${ }^{(2)}$.

With regard to hospitalized older adults, a study conducted in Portugal sought to estimate the effect of PI on the increase in length of hospital stay and the gains in health acquired from nurses' preventive interventions. Data were collected for nine consecutive months and there were 8274 hospitalizations of people aged 65 and over, with an average hospital stay of $9-11$ days. Therefore, it was possible to identify the length of hospital stay according to the staging of a PI: a patient who develops PI stage 1 remains hospitalized for an extra $9.07 \%$ of time, stage 2 for a further $13.61 \%$, stage 3 for a further $22.28 \%$ and stage 4 for an extra $55.99 \%$. The author states that investigating is a fundamental act to justify prevention, aiming at sustainability and better care ${ }^{(3)}$.

This topic is relevant to clinical practice, especially with regard to nursing care, since the incidence of PI, "in addition to being related to the clinical condition of older adults, directly reflects the quality of care provided by health care professionals, as its prevention is easy to perform and low cost"(4).

In the context of prevention, nursing care for older adults at risk of developing PI is essential and should be focused on the search for information through a complete anamnesis and detailed physical examination, identifying the risk factors for PI and the specific nursing diagnoses, developing a care plan, implementing interventions and evaluating the outcome ${ }^{(5)}$. Therefore, the aim of this study was to develop nursing diagnoses and care plans for older adults with pressure injuries based on risk factors, with a view to prevent their occurrence in hospitalized older adults.

\section{METHOD}

\section{Type Of Study}

This is an exploratory, descriptive, cross-sectional, quantitative study.

\section{SCENARIO}

It was conducted at a university hospital located in a municipality in the state of Rio Grande do Sul. This hospital is linked to a Federal Higher Education Institution (HEI).

\section{Population}

The inclusion criterion comprised all medical records of patients aged 60 years or older admitted to the mentioned unit during the data collection period. The exclusion criteria were selected according to the objectives of the article; medical records with incomplete information, patients who already had an installed PI and patients who did not have a Braden scale (BS) score were excluded. A total of 101 medical records were included in the study. The following were excluded: one with incomplete information; 11 from patients who already had PI; and two who did not have BS. Eighty-seven participants remained.

\section{Data Collection}

Data collection was performed on medical records of older adults admitted to the Medical Clinic Unit of the University Hospital. The initial collection was performed between February 7 and May 31, 2019. From April of the same year, data were extracted for the development of this article.

An instrument containing sociodemographic issues, clinical history, reason for hospitalization and medications administered was used to assist in the collection and registration of data. The following questions were selected to answer the objectives of this article: sex; age; marital status; monthly income; chronic diseases; lifestyle habits (smoking and drinking); weight and height (BMI); laboratory tests (hematocrit, hemoglobin, blood glucose and leukocytes); restriction to the hospital diet; control of eliminations (urinary and intestinal); restricted positioning; need for mobility assistance; presence of PI; and finally, the BS score.

For variables related to laboratory tests, the following normal values were used: hematocrit of $45 \%$ to $52 \%$ for men and $37 \%$ to $48 \%$ for women; hemoglobin from $13.8 \mathrm{~g} / \mathrm{dl}$ to $17.2 \mathrm{~g} / \mathrm{dl}$ for men and from $12.1 \mathrm{~g} / \mathrm{dl}$ to $15.1 \mathrm{~g} / \mathrm{dl}$ for women; leukocytes from 4,300 to 10,800 cells per cubic millimeter ${ }^{(6)}$; and blood glucose from $60 \mathrm{mg} / \mathrm{dl}$ to $100 \mathrm{mg} / \mathrm{dl}^{(7)}$. The BMI reference values were used according to the Geriatrics and Gerontology Treaty ${ }^{(8)}$, as follows: underweight, less than or equal to 22; appropriate, greater than 22 and less than 27 ; and overweight, greater than or equal to 27 .

\section{Data Analysis and Treatment}

For the organization of data, a Microsoft ${ }^{\circledR}$ Excel 2016 spreadsheet containing a dictionary (codebook) was created. 
The Statistical Package for the Social Sciences ${ }^{\circledR}$ (SPSS), version 20.0 was used for fata analysis. A descriptive statistical analysis was performed with description of the absolute and relative frequency of the variables. An inferential analysis was also performed, in which the chi-square test was used to assess the association between the dependent categorical variable (risk of injury) and other variables. For inferential analyzes, the significance level of $\mathrm{p}<0.05$ was considered.

Based on the risk factors, a care plan with nursing interventions was proposed according to the taxonomy of the Nursing Interventions Classification (NIC) ${ }^{(9)}$. To this end, nursing diagnoses were assigned, considering their defining characteristics and related/risk factors from the North American Nursing Diagnosis Association International (NANDA-I). The nursing diagnoses are performed by the nurse after anamnesis and complete physical examination of the patient, which was not done in this study. Thus, the possible nursing diagnoses of patients in the sample were listed according to the (associated) risk factors for the development of $\mathrm{PI}^{(10)}$.

The Nursing Outcomes Classification (NOC) taxonomy was also used to assign the expected outcomes for each nursing diagnosis ${ }^{(11)}$.

\section{Ethical AspeCts}

This study is part of a macro project approved by the Research Ethics Committee under Opinion number 166/2018 with consent granted by the Teaching and Research Management of the hospital where it was developed. It complied with Resolution 466/2012 of the National Health Council, which concerns research with human beings.

\section{RESULTS}

Of the 87 elderly, $24(27.6 \%)$ were at risk for PI according to the BS. Of these, five (20.8\%) were at mild risk, $16(66.7 \%)$ at moderate risk, and three (12.5\%) at severe risk. Most of both hospitalized older adults at risk and those without risk had a partner and an income between two and three minimum wages. Hospitalized older adults at risk for injury differed in relation to sex and age group; most were female (54.2\%) and aged 80 years or over (37.5\%). No sociodemographic variable showed a statistically significant association $(\mathrm{p}<0.05)$ with the risk for PI. These data are shown in Table 1.

Most hospitalized older adults with or without risk for PI had chronic diseases, were smokers, were not alcoholics, had no urinary control, had no bowel control, had a normal diet, did not have restricted positioning, did not need mobility assistance and had adequate BMI. The profile of older adults at risk for injury was similar, with only a slightly higher percentage of people with restricted positioning and who needed mobility assistance, compared to those without risk. The only variable that differed completely was being bedridden, as those at risk were mostly bedridden and those without risk were not. In this sense, there was a significant
Table 1 - Frequency distribution of sociodemographic variables of hospitalized older adults according to the presence of risk for pressure injury - Rio Grande, RS, Brazil, 2019.

\begin{tabular}{|c|c|c|c|}
\hline Variable & No risk (n\%) & At risk $(n \%)$ & p-value \\
\hline Sex & & & 0.497 \\
\hline Female & $29(46)$ & $13(54.2)$ & \\
\hline Male & $34(54)$ & $11(45.8)$ & \\
\hline Total & $63(100)$ & $24(100)$ & \\
\hline Age group (years) & & & 0.225 \\
\hline $60-69$ & $30(47.6)$ & $7(29.2)$ & \\
\hline $70-79$ & $19(30.2)$ & $8(33.3)$ & \\
\hline 80 or older & $14(22.2)$ & $9(37.5)$ & \\
\hline Total & $63(100)$ & $24(100)$ & \\
\hline Marital status & & & 0.631 \\
\hline With partner & $39(63.9)$ & $14(58.3)$ & \\
\hline No partner & $22(26.1)$ & $10(41.7)$ & \\
\hline Total & $61(100)$ & $24(100)$ & \\
\hline Income* & & & 0.193 \\
\hline Up to 1.5 & $13(23.2)$ & $8(34.8)$ & \\
\hline 2 to 3 & $37(66.1)$ & $15(65.2)$ & \\
\hline More than 3 & $6(10.7)$ & $0(0.0)$ & \\
\hline Total & $56(100)$ & $23(100)$ & \\
\hline
\end{tabular}

* minimum wage at the time of data collection $=\mathrm{R} \$ 998.00$.

statistical association between the variables being bedridden, restricted positioning and needing mobility assistance and the presence of risk with a value of $p<0.001, p=0.019$ and $\mathrm{p}=0.002$ respectively, as shown in Table 2 .

Most hospitalized older adults, both at risk and without risk, had a hematocrit with a reference value below normal, hemoglobin below normal, normal blood glucose, normal leukocytes. The profile of older adults at risk for injury was similar, with only a higher percentage of people with hemogram and hemoglobin values below normal and with leukocytes above normal. However, there was no statistically significant association between variables related to laboratory tests and the presence of PI.

From these results, few variables showed a statistical relationship with the risk for developing PI, namely: being bedridden, restricted positioning in bed and the need for mobility assistance. Even so, as prevention occurs based on the knowledge and intervention in all factors contributing to the onset of injuries, all risk factors found in the medical records were considered for the development of the ND and the care plan, according to Chart 1 .

Based on the overview of NANDA - NIC - NOC connections for each pertinent nursing diagnosis, the care plan for patients at risk for developing PI was developed, according to the main nursing interventions of the NIC. Interventions related to patient mobility predominated (observed in all proposed nursing diagnoses), followed 
Table 2 - Frequency distribution of variables related to the health of hospitalized older adults according to the presence of risk for pressure injury - Rio Grande, RS, Brazil, 2019.

\begin{tabular}{|c|c|c|c|}
\hline Variable & No risk ( $\mathrm{n} \%)$ & At risk (n\%) & p-value \\
\hline Presence of chronic disease & & & 0.866 \\
\hline Yes & $38(60.3)$ & $14(58.3)$ & \\
\hline No & $25(39.7)$ & $10(41.7)$ & \\
\hline Total & $63(100)$ & $24(100)$ & \\
\hline Smoking & & & 0.534 \\
\hline Yes & $35(55.6)$ & $13(54.2)$ & \\
\hline No & $21(33.3)$ & $10(41.7)$ & \\
\hline Ex-smoker & $7(11.1)$ & $1(4.1)$ & \\
\hline Total & $63(100)$ & $24(100)$ & \\
\hline Alcoholic & & & 0.599 \\
\hline Yes & $8(12.7)$ & $3(12.6)$ & \\
\hline No & $48(76.2)$ & $20(83.3)$ & \\
\hline Ex-alcoholic & $7(11.1)$ & $1(4.1)$ & \\
\hline Total & $63(100)$ & $24(100)$ & \\
\hline Diet & & & 0.864 \\
\hline Normal & $57(90.5)$ & $22(91.7)$ & \\
\hline Changed & $6(9.5)$ & $2(8.3)$ & \\
\hline Total & $63(100)$ & $24(100)$ & \\
\hline Urinary control & & & 0.287 \\
\hline Yes & $14(22.2)$ & $8(33.3)$ & \\
\hline No & $49(87.8)$ & $16(66.7)$ & \\
\hline Total & $63(100)$ & $24(100)$ & \\
\hline Bowel control & & & 0.217 \\
\hline Yes & $15(24.2)$ & $9(37.5)$ & \\
\hline No & $47(75.8)$ & $15(62.5)$ & \\
\hline Total & $62(100)$ & $24(100)$ & \\
\hline Bedridden & & & $<0.001$ \\
\hline Yes & 0 & 17 & \\
\hline No & 62 & 6 & \\
\hline Total & $62(100)$ & $23(100)$ & \\
\hline Restricted positioning & & & 0.019 \\
\hline Yes & $3(4.9)$ & $5(21.7)$ & \\
\hline No & $58(95.1)$ & $18(78.3)$ & \\
\hline Total & $61(100)$ & $23(100)$ & \\
\hline $\begin{array}{l}\text { Need for mobility } \\
\text { assistance }\end{array}$ & & & 0.002 \\
\hline Yes & $8(12.9)$ & $8(47.5)$ & \\
\hline No & $54(87.1)$ & $9(52.5)$ & \\
\hline Total & $62(100)$ & $17(100)$ & \\
\hline BMI & & & 0.771 \\
\hline Low weight & $12(19.4)$ & $6(25.0)$ & \\
\hline Appropriate & $31(49.2)$ & $10(41.7)$ & \\
\hline Overweight & $20(31.4)$ & $8(33.3)$ & \\
\hline Total & $63(100)$ & $24(100)$ & \\
\hline
\end{tabular}

by interventions related to pressure control, supervision and nutrition control/monitoring. Last but not least, were interventions related to urinary/bowel incontinence and hygiene.

\section{DISCUSSION}

The BS is used as a health indicator in the context of patient safety because of its preventive nature and provision of support for an overall assessment of the risk for the development of $\mathrm{PI}^{(12)}$. In this sense, the $\mathrm{BS}$ was chosen as a tool to measure the risk of PI, as its use is predominant, compared to other predictive scales of $\mathrm{PI}^{(13-14)}$.

The total sample of the study, a literature review that aimed to identify predisposing factors for the onset of PI in older adults, corroborates the findings, since most articles analyzed in the review related the female sex to the risk for PI and in nine out of the 21 articles, the extreme age was indicated as a predisposing factor ${ }^{(4)}$. Likewise, in a study that aimed to assess the occurrence and risk factors for the development of PI in patients admitted to three units of a hospital in Minas Gerais, most participants who developed PI were older adults aged between 60 and 96 years, women and white ${ }^{(15)}$.

Among the variables manifested in patients at risk for developing PI, those related to mobility, such as being bedridden, having restricted positioning and needing mobility assistance stood out. Restricted positioning was considered when the patient has some type of limitation restricting his/her positioning in bed, such as, for example, fractures or surgical procedures. In addition, the need for mobility assistance is understood as the patient's need or not for an assistance device or help from family members/ caregivers when walking or moving outside the bed.

It is the nurse's responsibility to guide the rest of the team and family members/patients in an educational and informative way, regarding the care of changing decubitus, skin hydration, use of pneumatic mattresses, use of support cushions and pillows to protect vulnerable areas and use of equipment that assist in movement and positioning ${ }^{(14)}$. These precautions are aimed at preventing PI, especially in older adults with risk factors related to mobility, identified in the present study. These are some examples of easy-to-use and low-cost interventions for the institution, which, if not performed, can trigger skin involvement.

In the present study, laboratory tests did not show a statistically significant association with the risk of developing PI, although most patients at risk had hemogram and hemoglobin values below normal and leukocytes above normal. In a study conducted in the state of Paraná, the risk for PI showed a statistical association only with low levels of albumin ${ }^{(16)}$.

We highlight the importance of the nurse's knowledge about all biochemical parameters, which contributes to evidence-based practice in the prevention of PI, since by having mastered the biochemical indicators, the professional can develop a more assertive care plan. In this sense, the treatment and prevention of injuries are aspects that enhance the nurse's autonomy ${ }^{(16)}$. 
Chart 1 - Nursing diagnoses, related factors, expected nursing outcomes and interventions - Rio Grande, RS, Brazil, 2020.

\section{DOMAIN 4 - ACTIVITY/REST (Class 2 - activity/exercise)} IMPAIRED PHYSICAL MOBILITY

Related factors: decrease in muscle control; malnutrition; disuse; pain; sedentary lifestyle; physical deconditioning; decrease in muscle strength; activity intolerance; decrease in muscle mass; body mass index (BMl) percentile $>75$ age and sex appropriate; reluctance to initiate movement; decrease in endurance; joint stiffness.

\begin{tabular}{|c|c|}
\hline Expected outcomes & Nursing interventions \\
\hline Gait & Exercise therapy: ambulation \\
Balance & Exercise promotion: strength training \\
Eody mechanics performance & Exercise therapy: balance \\
Body mechanics promotion \\
Client satisfaction: functional assistance \\
Mobility & Exercise therapy: joint mobility \\
Exansfer performance & Exere therapy: muscle control
\end{tabular}

DOMAIN 4 - ACTIVITY/REST (Class 2 - activity/exercise) IMPAIRED BED MOBILITY

Related factors: environmental barrier; insufficient knowledge of mobility strategies; pain; physical deconditioning; insufficient muscle strength; obesity.

\begin{tabular}{|c|c|}
\hline Expected outcomes & Nursing interventions \\
\hline $\begin{array}{c}\text { Body positioning: self-initiated } \\
\text { Coordinated movement } \\
\text { Mobility }\end{array}$ & $\begin{array}{c}\text { Exercise promotion: strength training } \\
\text { Exercise therapy: muscle control }\end{array}$ \\
\hline
\end{tabular}

DOMAIN 4 - ACTIVITY/REST (Class 2 - activity/exercise) IMPAIRED WALKING

Related factors: insufficient knowledge of mobility strategies; pain; physical deconditioning; insufficient muscle strength; decrease in endurance.

\begin{tabular}{|c|c|}
\hline Expected outcomes & Nursing interventions \\
\hline $\begin{array}{l}\text { Locomotion: walking } \\
\text { Balance }\end{array}$ & $\begin{array}{l}\text { Exercise therapy: ambulation } \\
\text { Exercise therapy: balance }\end{array}$ \\
\hline \multicolumn{2}{|c|}{$\begin{array}{l}\text { DOMAIN } 4 \text { - ACTIVITY/REST (Class } 4 \text { - Cardiovascular/pulmonary responses) } \\
\text { INEFFECTIVE PERIPHERAL TISSUE PERFUSION }\end{array}$} \\
\hline \multicolumn{2}{|c|}{ Related factors: insufficient knowledge of disease process; insufficient knowledge of aggravating factors; smoking } \\
\hline Expected outcomes & Nursing interventions \\
\hline $\begin{array}{c}\text { Tissue integrity: skin and mucous membranes } \\
\text { Tissue perfusion: peripheral } \\
\text { Cutaneous sensory function } \\
\text { Circulation status }\end{array}$ & $\begin{array}{c}\text { Pressure injury prevention } \\
\text { Positioning } \\
\text { Skin surveillance } \\
\text { Temperature regulation } \\
\text { Blood pressure control } \\
\text { Lower extremity monitoring } \\
\text { Fluid monitoring } \\
\text { Hydroelectrolytic management }\end{array}$ \\
\hline \multicolumn{2}{|c|}{$\begin{array}{l}\text { DOMAIN } 4 \text { - ACTIVITY/REST (Class } 5 \text { - self-care) } \\
\text { TOILETING SELF-CARE DEFICIT }\end{array}$} \\
\hline \multicolumn{2}{|c|}{ Related factors: anxiety; environmental barrier; impaired ability to transfer; pain; fatigue; weakness; impaired mobility; decrease in motivatio } \\
\hline Expected outcomes & Nursing interventions \\
\hline Self-care: toileting & $\begin{array}{c}\text { Urinary/bowel incontinence care } \\
\text { Exercise promotion } \\
\text { Perineal care } \\
\text { Skin surveillance }\end{array}$ \\
\hline \multicolumn{2}{|c|}{$\begin{array}{l}\text { DOMAIN } 9 \text { - STRESS COPING/TOLERANCE } \\
\text { ANXIETY (Class } 2 \text { - coping responses) }\end{array}$} \\
\hline \multicolumn{2}{|c|}{ Related factors: threat to current status; threat of death; stressors; unmet needs. } \\
\hline Expected outcomes & Nursing interventions \\
\hline $\begin{array}{l}\text { Anxiety self-control } \\
\text { Anxiety level }\end{array}$ & $\begin{array}{c}\text { Active listening } \\
\text { Decision-making support } \\
\text { Crisis intervention } \\
\text { Dementia management } \\
\text { Vital signs monitoring } \\
\text { Medication administration } \\
\text { Anxiety reduction } \\
\text { Environmental management }\end{array}$ \\
\hline
\end{tabular}




\begin{tabular}{|c|c|}
\hline \multicolumn{2}{|c|}{$\begin{array}{c}\text { DOMAIN } 11 \text { - SAFETY AND PROTECTION (Class } 2 \text { - physical injury) } \\
\text { RISK FOR IMPAIRED SKIN NTEGRITY }\end{array}$} \\
\hline \multicolumn{2}{|c|}{ Related factors: excretions; hydration; pressure over bony prominence; secretions; moisture. } \\
\hline Expected outcomes & Nursing interventions \\
\hline $\begin{array}{c}\text { Tissue integrity: skin and mucous membranes } \\
\text { Body positioning: self-initiated } \\
\text { Hydration } \\
\text { Immobility consequences: physiological } \\
\text { Immune status } \\
\text { Nutritional status } \\
\text { Nutritional status: food and fluid intake } \\
\text { Urinary continence } \\
\text { Weight: body mass }\end{array}$ & $\begin{array}{l}\text { Bath } \\
\text { Bed rest care } \\
\text { Bowel incontinence care } \\
\text { Urinary incontinence care } \\
\text { Lower extremity monitoring } \\
\text { Nutrition management } \\
\text { Positioning } \\
\text { Blood pressure control } \\
\text { Skin surveillance } \\
\text { Pressure injury prevention }\end{array}$ \\
\hline \multicolumn{2}{|c|}{$\begin{array}{c}\text { DOMAIN } 11 \text { - SAFETY AND PROTECTION (Class } 2 \text { - physical injury) } \\
\text { RISK FOR PRESSURE INJURY }\end{array}$} \\
\hline \multicolumn{2}{|c|}{$\begin{array}{l}\text { Related factors: surface friction; insufficient caregiver knowledge of pressure injury prevention; insufficient knowledge of aggravating factors; sel } \\
\text { care deficit; shearing forces; incontinence; inadequate nutrition; extended period of immobility on hard surface; pressure over bony prominenc } \\
\text { decrease in mobility; smoking. }\end{array}$} \\
\hline Expected outcomes & Nursing interventions \\
\hline $\begin{array}{c}\text { Mobility } \\
\text { Nutritional status: food and fluid intake } \\
\text { Risk control } \\
\text { Risk detection } \\
\text { Self-care status } \\
\text { Sensory function } \\
\text { Tissue integrity: skin and mucous membranes } \\
\text { Transfer performance }\end{array}$ & $\begin{array}{l}\text { Energy management } \\
\text { Exercise promotion } \\
\text { Exercise therapy: ambulation } \\
\text { Nutritional management } \\
\text { Pressure control } \\
\text { Surveillance }\end{array}$ \\
\hline \multicolumn{2}{|c|}{$\begin{array}{l}\text { DOMAIN } 11 \text { - SAFETY AND PROTECTION (Class } 5 \text { - defensive processes) } \\
\text { RISK FOR ALLERGY RESPONSE }\end{array}$} \\
\hline \multicolumn{2}{|c|}{ Related factors: exposure to allergen (moisture by body fluids) } \\
\hline Expected outcomes & Nursing interventions \\
\hline Allergic response: localized & Allergy management \\
\hline
\end{tabular}

In this context, a study with the objective of "establishing relationships between nursing interventions and outcomes for the diagnosis of risk for pressure injury in critically ill patients", established outcomes and interventions for each factor/domain present in the BS: $100 \%$ of patients were bedridden, $60.3 \%$ had a higher chance of friction/shear and $52.4 \%$ had impaired nutrition ${ }^{(17)}$. The relationship with the current study stands out, in which interventions on mobility predominated. We emphasize the importance of each domain of the BS as a risk factor for the development of the care plan, as well as the need for its presence in patients' medical records.

In addition to the risk factors already discussed, regarding mobility, pressure control and skin supervision, the nutritional aspect stands out, where nurses must act actively, since they have daily contact with the patient and observe factors such as swallowing and acceptance of the offered diet. A recent study highlighted the early performance of nutritional assessment, which is a fundamental tool in the recognition of malnourished or nutritionally at-risk older adults. The nutritional status of patients should be assessed in such a way that the supply of energy and protein is guaranteed as recommended by the guidelines ${ }^{(18)}$.
Last but not least, interventions related to urinary/ bowel incontinence and hygiene appeared. Incontinence has physiological and psychological consequences, since patients often do not accept to use geriatric diapers. When their use is necessary, it can contribute to skin moisture and predispose to the occurrence of PI. In a current study, when analyzing the use of diapers in adult and older adult patients, the authors emphasized this is a non-standard practice, in which cognition, mobility and incontinence criteria are not screened ${ }^{(19)}$.

In this sense, a study developed with the objective of analyzing the sociodemographic and clinical profile associated with skin care and wounds in hospitalized older adults identified a high number of nursing interventions associated with skin care ${ }^{(19)}$. The need for nursing interventions proved to be relevant both in the association between prolonged hospitalization, chronic diseases and aging, which demonstrated a strong relationship with PI, and in the association between extremes of age and skin aging ${ }^{(20)}$.

In the present study, possible interventions with older adults that can be implemented within the hospital environment were considered, since a hospitalization period requires the participation of a multidisciplinary team. Each 
nursing intervention considers several activities that can be developed by nurses, and according to the NIC, many interventions require specialized nurse training, whereas others describe practices that can be developed by technicians, although they must always be planned and evaluated by nurses ${ }^{(9)}$.

New research on nursing interventions capable of acting in the prevention of PI is encouraged, especially in older adult patients, as this is a vulnerable population to diseases, and if hospital stay is necessary, it should be quick and resolving, because events like PIs can be fatal in these clients.

Pressure injuries represent a problem that affects patients, the health system and the work team, especially nursing professionals. In this sense, this study contributes to the health area when thinking about the various consequences of the lack of PI prevention, especially in the hospital environment and with older adult patients, where this disease can lead to death.

The limitations of this study regard the information contained in the medical records, since the BS could not be analyzed considering its domains but only the final score.

\section{CONCLUSION}

The nursing outcomes and interventions were proposed in view of the possible diagnoses for these patients, highlighting interventions that encourage patient mobility, pressure control, skin supervision, nutrition, incontinence and hygiene.

By developing nursing diagnoses and interventions, it is possible to systematize the care provided by nurses and stimulate clinical reasoning in order to provide qualified and individualized care for the individual needs of older adults with skin injuries from the identification of risk factors to the assessment of expected outcomes. Aiming at preventing pressure injuries, the present study contributes to the dissemination of a care plan designed specifically for hospitalized older adults, highlighting the importance of the nurse's mastery of the scientific tools involved in the profession.

\section{RESUMO}

Objetivo: Elaborar diagnósticos de enfermagem e plano de cuidados para indivíduos idosos com lesão por pressão com base nos fatores de risco, visando a prevenção de sua ocorrência nas pessoas idosas hospitalizadas. Método: Estudo exploratório, descritivo, transversal com abordagem quantitativa, realizado na Unidade de Clínica Médica de um Hospital Universitário, com 87 prontuários. Resultados: Entre as pessoas idosas que apresentaram algum risco para o desenvolvimento de lesão por pressão, verificou-se uma prevalência do sexo feminino, com mais de 80 anos de idade e classificados em risco moderado na Escala de Braden. Destacaram-se as intervenções de enfermagem que estimulam a mobilidade do paciente, controle da pressão, supervisão da pele, nutrição, incontinência e higiene. Conclusão: A enfermagem tem papel importante na manutenção da integridade da pele dos pacientes. Cabe salientar a utilização das escalas preditivas de lesão como dispositivo complementar à clínica, para auxiliar no diagnóstico de enfermagem com vistas às intervenções direcionadas aos fatores de risco.

\section{DESCRITORES}

Idoso; Hospitalização; Lesão por Pressão; Diagnóstico de Enfermagem; Cuidados de Enfermagem.

\section{RESUMEN}

Objetivo: Desarrollar diagnósticos y planes de atención de enfermería para adultos mayores con lesiones por presión basados en factores de riesgo, con el objetivo de prevenir su ocurrencia en adultos mayores hospitalizados. Método: Estudio exploratorio, descriptivo, transversal y cuantitativo realizado en la Unidad de Clínica Médica de un Hospital Universitario con 87 historias clínicas. Resultados: Entre los adultos mayores con algún riesgo de desarrollar una lesión por presión, hubo una prevalencia del sexo femenino, mayor de 80 años y clasificado en riesgo moderado en la Escala de Braden. Destacaron las intervenciones de enfermería que favorecen la movilidad del paciente, el control de la presión, la supervisión cutánea, la nutrición, la incontinencia y la higiene. Conclusión: La enfermería tiene un papel importante en el mantenimiento de la integridad de la piel de los pacientes. Cabe destacar el uso de escalas predictivas de lesiones como complemento a la práctica clínica para ayudar en el diagnóstico de enfermería con miras a intervenciones dirigidas a factores de riesgo.

\section{DESCRIPTORES}

Anciano; Hospitalización; Úlcera por Presión; Diagnóstico de Enfermería; Atención de Enfermería.

\section{REFERENCES}

1. National Pressure Ulcer Advisory Panel. Pressure injury stages: overview of our updated staging definitions as of 2016. Washington: NPUAP; 2016.

2. Paraná. Secretaria de Estado da Saúde; Superintendência de Atenção à Saúde. Avaliação multidimensional do idoso [Internet]. Curitiba: SESA; 2017 [cited 2020 ago. 25]. Available from: http://www.saude.pr.gov.br/arquivos/File/Apostila_Idoso241017.pdf

3. Venâncio B, Alves E, Ruano C, Matos D, Valente S, Abreu N, et al. O impacto económico da prevenção de úlceras de pressão num hospital universitário. J Bras Econ Saúde. 2019;11(1):64-72. https://doi.org/10.21115/JBES

4. Souza NR, Freire DA, Souza MAO, Santos ICRV, Santos LV, Bushatsky M. Fatores predisponentes para o desenvolvimento da lesão por pressão em pacientes idosos: uma revisão integrativa. Estima. 2017;15(4):229-39. https://doi.org/10.5327/Z1806-3144201700040007

5. Lopes TF, Fernandes BKC, Alexandre SG, Farias FS, Day TC, Freitas MC. Medicamentos e sua relação com o desenvolvimento de lesão por pressão em idosos hospitalizados. Rev Online Pesq Cuid Fundam. 2020;12:212-16. https://doi.org/10.9789/2175-5361.rpcfo.v12.7993 
6. Organização Pan-Americana da Saúde. Hemograma completo. Brasília: OPAS; 2017.

7. Organização Pan-Americana da Saúde. Conheça os níveis de açúcar no sangue. Brasília: OPAS; 2019.

8. Freitas VF, Costa EFA, Galera SC. Avaliação geriátrica ampla. In: Freitas EV, Py L. Tratado de geriatria e gerontologia. $4^{a}$ ed. Rio de Janeiro: Guanabara Koogan; 2016. p. 415-54.

9. Bulechek GM, Butcher HK, Dochterman JM. Classificação das Intervenções de Enfermagem (NIC). $5^{\text {a }}$ ed. Rio de Janeiro: Elsevier; 2010.

10. NANDA Internacional. Diagnósticos de enfermagem da NANDA-I: definições e classificação 2018-2020. Porto Alegre: Artmed; 2018.

11. Moorhead SUE, Johnson M, Maas ML, Swanson FE. Classificação dos Resultados de Enfermagem (NOC): mensuração dos resultados em saúde. $5^{a}$ ed. Rio de Janeiro: Elsevier; 2016.

12. Debon R, Fortes VLF, Rós ACR, Scaratti M. A visão de enfermeiros quanto a aplicação da Escala de Braden no paciente idoso. Rev Online Pesqui Cuid Fundam. 2018;10(3):817-23. http://dx.doi.org/10.9789/2175-5361.2018.v10i3.817-823

13. Castanheira LS, Werli-Alvarenga A, Correa AR, Campos DMP. Escalas de predição de risco para lesão por pressão em pacientes criticamente enfermos: revisão integrativa. Enferm Foco. 2018;9(2):55-61.

14. Salgado LP, Pontes APM, Costa MM, Gomes ENF. Escalas preditivas utilizadas por enfermeiros na prevenção de lesão por pressão. Saber Digital. 2018;11(1):18-35.

15. Barbosa JM, Salomé GM. Occurrence of pressure injury in patients hospitalized in a school hospital. Estima. 2018;16:e2718. https://doi. org/10.30886/estima.v16.523

16. Fernandes LM, Silva L, Oliveira JLC, Souza VS, Nicola AL. Associação entre predição para lesão por pressão e marcadores bioquímicos. Rev Rene. 2016;17(4):490-7. https://doi.org/10.15253/2175-6783.2016000400008

17. Caldini LN, Silva RA, Melo GAA, Pereira FGF, Frota NM, Caetano JA. Intervenções e resultados de enfermagem para risco de lesão por pressão em pacientes críticos. Rev Rene. 2017;18(5):598-605. https://doi.org/10.15253/2175-6783.2017000500006

18. Oliveira KDL, Haack A, Fortes RC. Estado nutricional de idosos e prevalência de lesão por pressão na assistência domiciliar. Rev Enferm Atual. 2017;(n.esp). https://doi.org/10.31011/reaid-2017-v.2017-n.0-art.551

19. Bitencourt GR, Alves LAF, Santana RF. Prática do uso de fraldas em adultos e idosos hospitalizados: estudo transversal. Rev Bras Enferm. 2018;71(2). http://dx.doi.org/10.1590/0034-7167-2016-0341

20. Silva CFR, Santana RF, Oliveira BGRB, Carmo TG. High prevalence of skin and wound care of hospitalized elderly in Brazil: a prospective observational study. BCM Res Notes. 2017;10(1):81. https://doi.org/10.1186/s13104-017-2410-6 